\title{
The Multifaceted Effects of Gut Microbiota on the Immune System of the Intestinal Mucosa
}

\author{
Takehiro Hirano and Hiroshi Nakase *(D) \\ Department of Gastroenterology and Hepatology, Sapporo Medical University School of Medicine, \\ Minami 1-jo Nishi 16-chome, Chuo-ku, Sapporo 060-8543, Japan; t.hirano@sapmed.ac.jp \\ * Correspondence: hiropynakase@gmail.com; Tel.: +81-11-611-2111
}

Citation: Hirano, T.; Nakase, H. The Multifaceted Effects of Gut Microbiota on the Immune System of the Intestinal Mucosa. Immuno 2021, 1, 583-594. https://doi.org/10.3390/ immuno1040041

Academic Editor: Paul de Vos

Received: 11 November 2021 Accepted: 8 December 2021 Published: 13 December 2021

Publisher's Note: MDPI stays neutral with regard to jurisdictional claims in published maps and institutional affiliations.

Copyright: (C) 2021 by the authors. Licensee MDPI, Basel, Switzerland. This article is an open access article distributed under the terms and conditions of the Creative Commons Attribution (CC BY) license (https:// creativecommons.org/licenses/by/ $4.0 /)$.

\begin{abstract}
The gut microbiota has diverse microbial components, including bacteria, viruses, and fungi. The interaction between gut microbiome components and immune responses has been studied extensively over the last decade. Several studies have reported the potential role of the gut microbiome in maintaining gut homeostasis and the development of disease. The commensal microbiome can preserve the integrity of the mucosal barrier by acting on the host immune system. Contrastingly, dysbiosis-induced inflammation can lead to the initiation and progression of several diseases through inflammatory processes and oxidative stress. In this review, we describe the multifaceted effects of the gut microbiota on several diseases from the perspective of mucosal immunological responses.
\end{abstract}

Keywords: gut microbiota; mucosal immunity; metabolites; inflammatory bowel disease; colon carcinogenesis; COVID-19

\section{Introduction}

The human gastrointestinal tract harbors innumerable bacteria, which constitute the gut microbiota [1]. The gut microbiota has diverse microbial components, including bacteria, viruses, and fungi. Research on gut microbiota began with studies conducted by Leeuwenhoek in the 1680s. He observed human feces using a microscope and found several small organisms, including bacteria. Numerous bacterial species have since been cultured and identified in human feces. In recent years, next-generation sequencing (NGS) has markedly facilitated our understanding of the intestinal microbiome. NGS technology has revealed that most of the intestinal bacteria can be classified as Firmicutes, Bacteroidetes, Actinobacteria, Proteobacteria, Fusobacteria, and Verrucomicrobia. Among them, Firmicutes and Bacteroidetes constitute approximately $90 \%$ of the total intestinal bacterial population [2]. The phylum Firmicutes is composed of genera such as Lactobacillus, Bacillus, Clostridium, Enterococcus, and Ruminococcus. Bacteroidetes consists of genera such as Bacteroides and Prevotella. The phylum Actinobacteria is mainly represented by the genus Bifidobacterium [3].

The gastrointestinal tract plays a crucial role in the immune system. Intestinal epithelial cells (IECs) and lamina propria are the effector sites of the intestinal immune system and contain various immune cells. IECs act as crucial regulators of mucosal immunity by serving as a barrier between enterocytes and the gut lumen [4]. For the intestinal mucosa, gut microbiota could present an extrinsic factor that threatens the maintenance of immune homeostasis. However, the gut microbiota lives in synergy with the host environment [5]. The commensal microbiome resides in a habitable niche in the gut lumen while regulating various host physiological functions, which play a protective role in the mucosal immune system against pathogens. In addition, the gut microbiota has beneficial effects on nutrition and metabolism. The symbiotic relationship between the host and gut microbiota plays a prominent role in the maintenance of gut homeostasis [6]. 
Contrastingly, an imbalance in the microbial community, which is called dysbiosis, is associated with multiple diseases. Dysbiosis-induced inflammation can lead to the initiation and progression of various intestinal diseases, including inflammatory bowel disease (IBD) and colon cancer. Additionally, a relationship between dysbiosis and extra-intestinal diseases, such as asthma, diabetes, atherosclerosis, and autism spectrum disorders, has been reported [7]. Recent reports show that gut dysbiosis could be a modifier in the intestinal lesion of Coronavirus Disease 2019 (COVID-19) [8].

In this review, we describe the multifaceted effects of gut microbiota on the intestinal mucosa as well as the accumulating evidence of severe acute respiratory syndrome coronavirus-2 (SARS-CoV-2) infections in the gastrointestinal tract.

\section{Role of the Gut Microbiome in Host Intestinal Homeostasis}

The gut microbiota plays a pivotal role in forming the intestinal environment of the host through its involvement in metabolism, host defense, and the immune system [6]. These functions are essential for host energy acquisition and intestinal homeostasis $[9,10]$.

\subsection{Dietary Metabolism and Gut Microbiota}

Dietary components (e.g., carbohydrates, lipids, and proteins) are digested into gut metabolites through the activities of enzymes secreted from the digestive organs [4].

Monosaccharides, hydrolyzed products of carbohydrates, are metabolized to pyruvate by glycolysis in the small intestine [11]. Firmicutes (Lachnospiraceae and Ruminococcaceae) and Bacteroides convert indigestible carbohydrates, such as dietary fiber, into short-chain fatty acids (SCFAs) [12]. In the intestinal environment, SCFAs consist mainly of acetate, propionate, and butyrate, which are the major anions in the colon [13]. SCFAs are absorbed by colonocytes and become a major energy source for colonic epithelial cells [14]. Among SCFAs, butyric acid is known to play a protective role in the intestinal tract through multiple mechanisms. Butyrate increases the mucosal barrier integrity through mucin secretion $[15,16]$, induces the differentiation of gut monocytes into anti-microbial macrophages [17], and maintains the homeostasis of regulatory T-cells (Tregs) [18], which provides a protective effect against colitis [19].

Dietary lipids are digested into fatty acids by lipases. Fatty acids act as energy sources and form cell membrane components, such as phospholipids [20]. Polyunsaturated fatty acids (PUFAs), such as linoleic acid and $\alpha$-linolenic acid, have physiologically important roles and are called essential fatty acids, because they are not synthesized in the human body. Bifidobacterium strains and Propionibacterium freudenreichii are reported to produce conjugated linoleic acids (CLAs). Firmicutes (Lactobacillus plantarum) also induce the production of CLAs, hydroxy fatty acids, and oxo fatty acids through PUFA-saturating enzymes. 10-Hydroxy-cis-12-octadeccenoid acid, a metabolite of linoleic acid, is produced by bacteria expressing the myosin cross-reactive antigen protein (e.g., Lactobacillus, Bifidobacterium, Streptococcus, and Stenotrophomonas) [4].

Dietary proteins are digested into tripeptides, dipeptides, and amino acids by proteases secreted in the stomach and pancreas. Proteins are primarily digested by host-derived proteases, but some gut microbes also produce proteases. These bacteria-derived proteases are mainly produced by amino acid-fermenting bacteria (Firmicutes and Proteobacteria) $[1,21]$. Thus, the role of the gut microbiome in the host metabolism is suitably documented.

\subsection{Gut Microbiota and Defense from Pathogens}

The intestinal epithelium plays a fundamental role as a barrier against pathogenic infections. As a part of this barrier mechanism, the intestinal epithelium is lined with tight junctions, which separate the commensal microbiome from the underlying tissues [22]. Along with the epithelium, the intestinal mucus plays a protective role against pathogenic infections. Mucin regulates virulence factors and biofilm formation and contributes to the coexistence of beneficial bacteria, such as Lactobacillus and Bifidobacterium, promoting the reduction of pathogenic bacteria $[23,24]$. Johansson et al. reported the attenuation of the 
mucus barrier function in germ-free mice and demonstrated a gain-of-function following the administration of a conventional mouse microbiome [25]. This indicates the role of the microbiome-mucus interaction in mucosal layer maturation.

The commensal microbiome and pathogens are known to compete for physical and nutritional niches in the gut, and this phenomenon is called colonization resistance [26,27]. Antibiotic use and dietary habits alter the microbiome composition and can reduce colonization resistance, resulting in mild colitis and vulnerability to infection [22]. Quorum sensing, a density monitoring and transcriptional regulation system in bacteria, is associated with this competition. In quorum sensing, bacteria detect a high microbial density by sensing signaling substances particular to the bacterium and thereby regulate gene transcription [28]. The quorum sensing system is used by pathogens to construct hostile environments (Figure 1). However, Piewngam et al. demonstrated that treatment with the probiotic Bacillus eliminated Staphylococcus aureus, implying an inhibitory role of the commensal microbiome in the quorum sensing of pathogens [29].

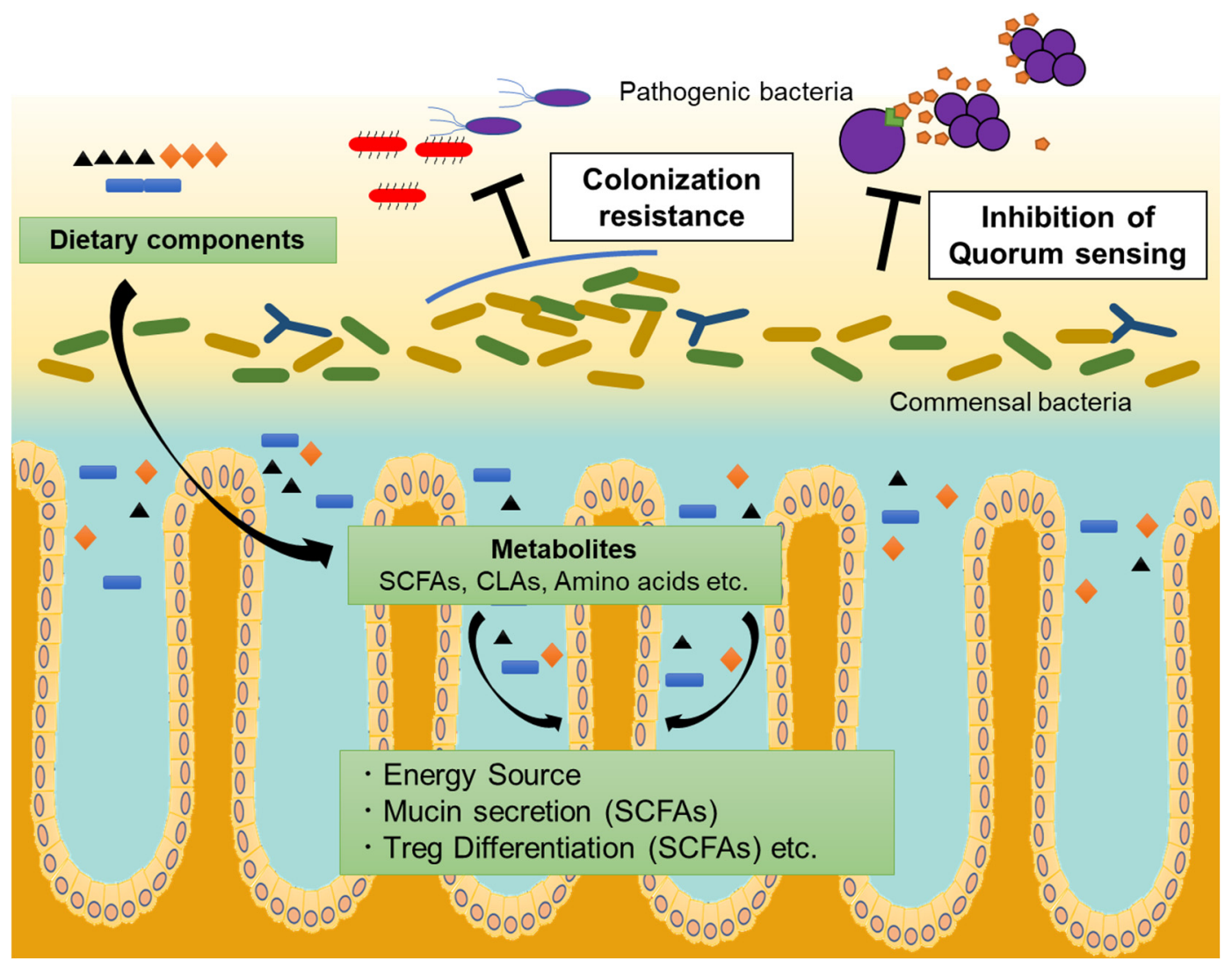

Figure 1. Role of the gut microbiota in dietary metabolism and defense from pathogens. The commensal microbiome shows mucosal protective effects through dietary metabolism and colonization resistance. In addition, the commensal microbiome inhibits quorum sensing, which has a protective effect on the gut mucosa.

\subsection{Gut Microbiota as Activators of Host Mucosal Immunity}

The development and composition of the gut microbiota are closely linked to the development of the immune system. In germ-free conditions, mice exhibit immature intestinal lymphoid tissues, which can cause immunodeficiency [30]. In addition, the levels of antimicrobial peptides [31-33] and $\operatorname{IgA}[34,35]$ in the intestine are decreased under germ-free conditions. These deficits and immune abnormalities are restored by the reconstitution of the gut microbiota in these mice [36]. Segmented filamentous bacteria (SFB) promote the maturation of the mucosal immune system. Colonization with SFB increases the proportion of T helper (Th) 17 cells in the mucosal lamina propria, upregulates the expression of genes associated with inflammation and antimicrobial defense, and 
enhances resistance to intestinal pathogens [36-39]. The gut microbiota is also involved in the regulation of Th cell proportions through the activity of bacterial metabolites. As mentioned previously, Atarashi et al. reported the differentiation and expansion of colonic Tregs by butyrate-producing bacterial strains (Clostridium clusters IV, XIVa, and XVIII) from a healthy human fecal sample [19].

The interaction between gut fungi and mucosal immunity has also been extensively studied. Pattern recognition receptor (PRR)-expressing immune cells, such as monocytes and mononuclear phagocytes, are involved in this immune response. PRRs are cell-surface receptors that recognize pathogen-associated molecular patterns (PAMPs) [40]. Toll-like receptors (TLRs), C-type lectin receptors (CLRs), and nucleotide-binding oligomerization domain (NOD)-like receptors (NLRs) are representative PRRs. PRR activation induces the secretion of chemokines and cytokines, which are essential for a protective immune response [41]. PRR expression is known to increase in the distal intestine and is thought to be related to bacterial density [42]. Table 1 lists the major PRRs and their targets. The pattern of TLR expression differs depending on the intestinal site. Price et al. demonstrated that TLR expression was higher in colonic IECs than in small intestinal IECs and that TLR5 expression was restricted to Paneth cells in the small intestine [43]. In the intestinal epithelium, the expression and subcellular localization of each TLR is specifically regulated, allowing the epithelium to be appropriately ligand-stimulated. The expression of TLR2, which predominantly recognizes Gram-positive bacteria, and TLR4, which recognizes Gram-negative bacteria, is reported to be low in normal intestinal epithelial cells [44,45], but it is increased in IBD patients $[46,47]$. TLR5, which recognizes flagellin, is expressed on the basolateral side of intestinal epithelial cells and is known to respond to the invasion of flagellates, such as Salmonella [48].

Table 1. Representative pattern recognition receptors in the intestine and their targets.

\begin{tabular}{|c|c|c|c|c|c|}
\hline Family & Localization & PAMPs & $\begin{array}{c}\text { Target } \\
\text { Microorganisms }\end{array}$ & $\begin{array}{c}\text { Target } \\
\text { Molecules }\end{array}$ & $\begin{array}{c}\text { Signal } \\
\text { Molecules }\end{array}$ \\
\hline \multirow{8}{*}{ TLRs } & \multirow{5}{*}{$\begin{array}{c}\text { Plasma } \\
\text { Membrane }\end{array}$} & TLR2 & Bacteria & Peptidoglycan & MyD88 \\
\hline & & TLR2 \& TLR1 & Mycobacteria & $\begin{array}{c}\text { Triacyl } \\
\text { lipopeptides }\end{array}$ & MyD88 \\
\hline & & TLR2 \& TLR6 & $\begin{array}{l}\text { Mycoplasma } \\
\text { Streptococcus }\end{array}$ & $\begin{array}{l}\text { Diacetylated } \\
\text { lipopeptides }\end{array}$ & MyD88 \\
\hline & & TLR4 & Gram negative bacteria & Lipopolysaccharide & MyD88 TRIF \\
\hline & & TLR5 & Bacteria & Flagellin & MyD88 \\
\hline & \multirow{3}{*}{$\begin{array}{c}\text { Internal } \\
\text { Membrane }\end{array}$} & TLR3 & Viruses & dsRNA & TRIF \\
\hline & & TLR7 \& TLR8 & Viruses & ssRNA & MyD88 \\
\hline & & TLR9 & $\begin{array}{c}\text { Bacteria } \\
\text { DNA viruses }\end{array}$ & CpG motifs of DNA & MyD88 \\
\hline \multirow[b]{2}{*}{ CLRs } & \multirow[b]{2}{*}{$\begin{array}{c}\text { Plasma } \\
\text { Membrane }\end{array}$} & Dectins & Fungi & Beta-1,3-glucans & CARD9 RAF1 \\
\hline & & $\begin{array}{l}\text { Mannose } \\
\text { receptor }\end{array}$ & Candida & Fungal mannans & Unknown \\
\hline \multirow{3}{*}{ NLRs } & \multirow{3}{*}{ Cytoplasm } & NOD1 & Gram negative bacteria & Diaminopimelic acid & RIP2 \\
\hline & & NOD2 & Bacteria & $\begin{array}{l}\text { Muramyl } \\
\text { dipeptide }\end{array}$ & RIP2 \\
\hline & & NLRP3 & $\begin{array}{c}\text { Listeria } \\
\text { Staphylococcus }\end{array}$ & Peptidoglycan & $\begin{array}{c}\text { ASC/ } \\
\text { caspase-1 }\end{array}$ \\
\hline
\end{tabular}

Among the PRRs listed in Table 1, Dectin-1 (a member of CLRs), has been reported as one of the most important PRRs comprising the crosstalk between fungi and intestinal mucosa. Dectin-1 recognizes the polysaccharide $\beta-1,3$ glucan motif on fungal cell walls and mediates host immune responses [41]. In a dextran sodium sulfate (DSS)-induced colitis model, more severe colitis was observed in Dectin-1 knockout (KO) mice than in wild-type (WT) mice, with a high abundance of opportunistic fungi (e.g., Candida 
and Trichosporon). Antifungal treatment with fluconazole reduced the severity of colitis in Dectin-1 KO mice. In a previous study, the production of inflammatory cytokines, interleukin (IL)-17, interferon (IFN)- $\gamma$, and tumor necrosis factor (TNF)- $\alpha$ was increased at the site of colitis in Dectin-1 KO mice [49]. Simultaneously, the researchers indicated that a polymorphism in the Dectin-1-coding gene worsened the ulcerative colitis (UC) disease severity in humans [49]. These studies suggest a protective role of Dectin-1 in the interaction with commensal fungi. CLR signaling pathways have also been studied in a caspase recruitment domain-containing protein 9 (CARD9)-deficient mouse model. CARD9 is a downstream molecule of various CLRs, including Dectin-1. CARD9 KO mice had reduced IL- 6 and IFN- $\gamma$ levels and Th17 cell count in the acute phase of DSS-induced colitis, with a decreased expression of IL-17A and IL-22 in mesenteric lymph nodes in the recovery phase [50]. A decrease in IL-22 levels in colonic epithelial cells was demonstrated with a reduction in the abundance of Lactobacillus spp. in CARD9 KO mice. Lactobacilli stimulate aryl hydrocarbon receptor expression, which induces the production of IL-22 from Th17 cells and Type-3 innate lymphoid cells [51].

\section{Gut Microbiota in the Pathogenesis of Intestinal Diseases}

\subsection{Gut Microbiota and IBD}

Dysbiosis may play a causative role in IBD. Under germ-free conditions, the disease severity of the IBD model has been found to be attenuated in multiple animal experiments [52]. IBD patients possess an increased proportion of members of the family Enterobacteriaceae and a decreased number of members from the phylum Firmicutes [53]. The reduction of biodiversity in the gut microbiota results in an increase in the proportion of pathogenic bacteria [54], which induces the loss of intestinal barrier integrity, constituting an aspect of IBD pathophysiology [55]. Similarly, the number of adherent invasive Escherichia coli. (AIEC) is increased in patients with active Crohn's disease [56]. AIEC directly disrupts epithelial barrier integrity by producing alpha-hemolysin, which leads to the release of proinflammatory cytokines [57]. Sulfate-reducing bacteria, such as Desulfovibrio, are also abundant in IBD patients, resulting in mucosal damage with the production of hydrogen sulfate [58]. In addition, the number of mucolytic bacteria (i.e., Ruminococcus gnavas and Ruminococcus terques) is increased in IBD patients, leading to the degradation of the mucus layer and pathogen penetration into colonocytes [59].

From the perspective of metabolites, Faecalibacterium prausnitzii (a bacterial species belonging to Clostridium cluster IV) is reported to have anti-inflammatory effects owing to butyrate production, which leads to the regulation of Tregs and Th17 cells [60]. In IBD patients, the concentration of SCFAs decreases owing to the reduction of the abundance of butyrate-producing bacteria $[61,62]$. Thus, dysbiosis is associated with IBD, but determining whether an imbalance in the gut microbiota is the cause of IBD or the result of colitis is difficult.

In contrast, therapeutic agents for IBD reportedly affect the composition of the gut microbiota. 5-aminosalicylic acid (5-ASA) inhibits the growth of sulfate-reducing bacteria and reduces fecal sulfide levels in patients with IBD [63]. Another study has demonstrated the potent effects of 5-ASA on bacterial gene expression involved in bacterial invasion and cellular metabolism [64]. Faecalibacterium prausnitzii abundance increases in IBD patients after the initiation of TNF- $\alpha$ antibody therapy [65]. In addition, thiopurine is reported to affect the concentration and adherence of gut microbiota [66], and glucocorticoid treatment affects the proportion of Clostridiales and Lactobacillaceae in the gut microbiota by downregulating the expression of the $M u c 2$ gene [67].

\subsection{Gut Microbiota and Colon Carcinogenesis}

Many studies have demonstrated that the gut microbiota plays an important role in the development of colorectal cancer (CRC). In a previous study, in a germ-free environment, intestinal tumor development was suppressed in genetically engineered mice, such as IL-10deficient and T-cell receptor $\beta$ chain/p53 double-deficient mice $[68,69]$. Metagenomic and 
metabolomic analyses have revealed that the composition of the gut microbiota depends on the CRC staging [70]. Richard et al. compared the composition of gut microbiota among patients with colitis-associated cancer (CAC), sporadic cancer (SC), and healthy populations. Their data demonstrated an increase in the proportion of the members of the family Enterobacteriaceae and genus Sphingomonas and a decrease in the abundance of members of the genera Fusobacterium and Ruminococcus in CAC patients compared with SC patients [71].

Studies show that probiotics have both suppressive [72,73] and promotive [74] effects on tumorigenesis. Bacterial stimulation of TLRs activates NF- $\mathrm{kB}$, which triggers tumor development and growth [75]. Azoxymethane (AOM)/DSS-induced colitic cancer was suppressed in TLR-4-deficient mice [76]. MyD88, an adaptor protein in TLR signaling, is also involved in tumorigenesis. In a mouse model of familial adenomatous polyposis (APC $\mathrm{Min} /+^{+}$mice), which spontaneously develops CRC, MyD88 deficiency reduced both CRC and benign polyp formation [77].

Studies on CAC models have shown that the gut microbiota can promote or suppress colitis and tumorigenesis. Bifidobacterium lactis inhibits NF-KB in IECs, preventing the development of acute colitis and CAC in mice [78]. Bacteroides fragilis causes enteritis and tumorigenesis by activating the signal transducer and activator of the transcription-3 pathway and subsequent induction of Th17 cells [79]. Arthur et al. demonstrated that Escherichia coli NC101 promoted invasive carcinoma in AOM-treated IL-10-deficient mice [80]. The attachment and effacement of mucosa-associated Escherichia coli downregulates the expression of mismatch repair proteins such as MSH2 and MLH1 [81].

Furthermore, metabolic products contribute to intestinal inflammation and carcinogenesis. The metabolism and absorption of SCFAs play a protective role in patients with UC and colon carcinogenesis. SCFAs and dietary fiber metabolites mitigate the clinical signs of DSS-induced colitis [82]. SCFA transporters (MCT1 and SMCT1) are expressed in IECs, while their expression is reduced in the DSS-induced CAC model [83]. Western-style diets, which contain a high proportion of long chain fatty acids (LCFAs), promote DSS-induced inflammation and accelerate the infiltration of macrophages, resulting in the development and progression of CRC [84]. Butyric acid also plays a crucial role in the induction of Tregs in the colon [85]. The number of Foxp3+ Tregs in the tumors of AOM/DSS-treated mice with CAC has been found to be higher than that in WT mouse tumors [86]. The recruitment of Treg plays a pivotal role in immune evasion in malignant tumors [87], and in colorectal cancer, increased Treg levels have been shown to correlate with prognosis $[88,89]$. Treg differentiation in the colonic mucosal lamina propria is gut microbiota-dependent, and the peripherally-generated Treg in the intestine includes ROR $\gamma \mathrm{t}+$ Treg [90]. A recent study revealed that dysplasia related to IBD intestinal inflammation has been accompanied with a high frequency of ROR $\gamma t+$ Treg cells with inflammatory properties. Furthermore, ROR $\gamma \mathrm{t}+$ Treg cells with a similar phenotype have been present in the peripheral blood. This influx of Treg into the peripheral blood is possibly modified by a mucosal barrier dysfunction due to IBD [91].

\section{Mucosal Immunity and Gut Microbiota in COVID-19 Patients}

COVID-19 is an infectious disease caused by SARS-CoV-2. COVID-19 is now a pandemic. According to the current World Health Organization release, more than 260 million people have been infected and 5.2 million people have died to date due to this disease [92].

Although SARS-CoV-2 mostly affects the respiratory system, the gastrointestinal tract is an extra-respiratory organ affected by SARS-CoV-2. Angiotensin-converting enzyme(ACE)-2 receptors, which function as host receptors of SARS-CoV-2, are highly expressed in the gastrointestinal tract [93]. ACE-2 mediates intestinal infection with SARSCoV-2, and viral replication occurs in enterocytes [94]. Gastrointestinal damage due to the viral invasion of enterocytes is considered a cause of gastrointestinal symptoms [95]. Nausea, vomiting, diarrhea, and loss of appetite have been reported in more than $50 \%$ of patients with COVID-19 [96-98]. A meta-analysis by Hayashi et al. indicated that the 
appearance of abdominal pain was significantly higher in patients with severe COVID-19 than in those with non-severe COVID-19 [99].

Generally, cytopathic effects occur after the SARS-CoV-2 invasion of enterocytes [100], followed by the activation of the innate immune system, resulting in the activation of inflammatory cytokines, such as TNF- $\alpha$, IL-1, and IL-6. Among these cytokines, IL-6 is considered the major proinflammatory cytokine in the intestinal lesions of COVID-19 [101].

However, SARS-CoV-2 infection is suggested to induce thrombotic microvascular injury. The small intestine is also thought to be one of the targets of COVID-19-related micro thrombotic disease, based on several endoscopic findings [102,103].

Several studies have reported dysbiosis in patients with COVID-19. Zuo et al. reported dysbiosis in COVID-19 patients based on a fecal microbiome analysis in comparison with healthy controls. The proportion of pathogens from the genera Candida and Aspergillus is increased in COVID-19 patients [104]. Gu et al. also reported a distinct bacterial diversity in COVID-19 patients, with a high abundance of opportunistic pathogens (Streptococcus, Rothia, Veillonella, and Actinomyces) [105]. Yeoh et al. showed an altered gut microbiome composition in COVID-19 patients, with a concordance of disease severity and concentrations of inflammatory cytokines and blood markers (i.e., C-reactive protein and lactate dehydrogenase) [106]. Multiple factors could interact in COVID-19-related dysbiosis, such as patient background (age and chronic diseases), gut infection with SARS-CoV-2, antibiotic use, and stress. Dysbiosis contributes to the promotion of intestinal inflammation, which leads to a hyper-inflammatory status in the gut resulting in severe COVID-19 symptoms [8]. Thus, intestinal dysbiosis can modify COVID-19 pathophysiology. The approach from the perspective of dysbiosis improvement could be a therapeutic strategy for COVID-19.

\section{Conclusions}

The mutual relationship between gut microbiota and intestinal immunity has implications for both homeostasis and pathogenesis. In terms of maintaining homeostasis, the commensal microbiome shows mucosal protective effects through dietary metabolism (especially butyrate synthesis) and colonization resistance. In addition, the commensal microbiome acts as a mucosal protector by inhibiting the cell-to-cell communication of pathogens. However, once dysbiosis occurs, it can lead to the initiation and progression of intestinal diseases such as IBD and colon cancer as well as multiple extra-intestinal diseases. In COVID-19, gut dysbiosis could be a modifier of intestinal lesions. Thus, the gut microbiota has multifaceted effects on host health.

The following issues are yet to be elucidated: (1) What is the ideal composition of the gut microbiota? (2) What are the most effective therapeutic interventions for dysbiosis? Besides, the type of dysbiosis that appears at clinically different phases of IBD and CRC has not been shown (i.e., before onset, at onset, during exacerbation, and during recovery). Therefore, the dilemma of causality remains unresolved. Further large-scale clinical and translational research studies are required to understand these issues. We strongly hope that a microbiome-based clinical approach could bring a paradigm shift in clinical medicine.

Author Contributions: Conceptualization, T.H. and H.N.; writing-original draft preparation, T.H.; writing-review and editing, H.N.; visualization, T.H.; supervision, H.N.; project administration, H.N. All authors have read and agreed to the published version of the manuscript.

Funding: This research received no external funding.

Institutional Review Board Statement: Not applicable.

Informed Consent Statement: Not applicable.

Conflicts of Interest: The authors declare no conflict of interest. 


\section{References}

1. Qin, J.; Li, R.; Raes, J.; Arumugam, M.; Burgdorf, K.S.; Manichanh, C.; Nielsen, T.; Pons, N.; Levenez, F.; Yamada, T.; et al. A human gut microbial gene catalogue established by metagenomic sequencing. Nature 2010, 464, 59-65. [CrossRef] [PubMed]

2. Arumugam, M.; Raes, J.; Pelletier, E.; Le Paslier, D.; Yamada, T.; Mende, D.R.; Fernandes, G.R.; Tap, J.; Bruls, T.; Batto, J.M.; et al. Enterotypes of the human gut microbiome. Nature 2011, 473, 174-180. [CrossRef]

3. Rinninella, E.; Raoul, P.; Cintoni, M.; Franceschi, F.; Miggiano, G.; Gasbarrini, A.; Mele, M.C. What Is the Healthy Gut Microbiota Composition? A Changing Ecosystem across Age, Environment, Diet, and Diseases. Microorganisms 2019, 7, 14. [CrossRef] [PubMed]

4. Gu, B.-H.; Kim, M.; Yun, C.-H. Regulation of Gastrointestinal Immunity by Metabolites. Nutrients 2021, 13, 167. [CrossRef] [PubMed]

5. Lazar, V.; Ditu, L.-M.; Pircalabioru, G.G.; Gheorghe, I.; Curutiu, C.; Holban, A.M.; Picu, A.; Petcu, L.; Chifiriuc, M.C. Aspects of Gut Microbiota and Immune System Interactions in Infectious Diseases, Immunopathology, and Cancer. Front. Immunol. 2018, 9, 1830. [CrossRef]

6. Nishida, A.; Inoue, R.; Inatomi, O.; Bamba, S.; Naito, Y.; Andoh, A. Gut microbiota in the pathogenesis of inflammatory bowel disease. Clin. J. Gastroenterol. 2018, 11, 1-10. [CrossRef] [PubMed]

7. Chin, V.K.; Yong, V.C.; Chong, P.P.; Nordin, S.A.; Basir, R.; Abdullah, M. Mycobiome in the Gut: A Multiperspective Review. Mediat. Inflamm. 2020, 2020, 9560684. [CrossRef]

8. Chen, J.; Hall, S.; Vitetta, L. Altered gut microbial metabolites could mediate the effects of risk factors in Covid-19. Rev. Med. Virol. 2021, 31, 1-13. [CrossRef]

9. Hooper, L.V.; Gordon, J.I. Commensal host-bacterial relationships in the gut. Science 2001, 292, 1115-1118. [CrossRef]

10. Wostmann, B.S. The germfree animal in nutritional studies. Annu. Rev. Nutr. 1981, 1, 257-279. [CrossRef]

11. Jang, C.; Hui, S.; Lu, W.; Cowan, A.J.; Morscher, R.J.; Lee, G.; Liu, W.; Tesz, G.J.; Birnbaum, M.J.; Rabinowitz, J.D. The Small Intestine Converts Dietary Fructose into Glucose and Organic Acids. Cell Metab. 2018, 27, 351-361.e3. [CrossRef] [PubMed]

12. Marchesi, J.R.; Adams, D.H.; Fava, F.; Hermes, G.D.; Hirschfield, G.M.; Hold, G.; Quraishi, M.N.; Kinross, J.; Smidt, H.; Tuohy, K.M.; et al. The gut microbiota and host health: A new clinical frontier. Gut 2016, 65, 330-339. [CrossRef] [PubMed]

13. Sun, M.; Wu, W.; Liu, Z.; Cong, Y. Microbiota metabolite short chain fatty acids, GPCR, and inflammatory bowel diseases. J. Gastroenterol. 2017, 52, 1-8. [CrossRef]

14. Pomare, E.W.; Branch, W.J.; Cummings, J.H. Carbohydrate fermentation in the human colon and its relation to acetate concentrations in venous blood. J. Clin. Investig. 1985, 75, 1448-1454. [CrossRef] [PubMed]

15. Jung, T.-H.; Park, J.H.; Jeon, W.-M.; Han, K.-S. Butyrate modulates bacterial adherence on LS174T human colorectal cells by stimulating mucin secretion and MAPK signaling pathway. Nutr. Res. Pract. 2015, 9, 343-349. [CrossRef]

16. Schilderink, R.; Verseijden, C.; Seppen, J.; Muncan, V.; van den Brink, G.R.; Lambers, T.T.; van Tol, E.A.; de Jonge, W.J. The SCFA butyrate stimulates the epithelial production of retinoic acid via inhibition of epithelial HDAC. Am. J. Physiol. Gastrointest. Liver Physiol. 2016, 310, G1138-G1146. [CrossRef] [PubMed]

17. Schulthess, J.; Pandey, S.; Capitani, M.; Rue-Albrecht, K.C.; Arnold, I.; Franchini, F.; Chomka, A.; Ilott, N.E.; Johnston, D.; Pires, E.; et al. The Short Chain Fatty Acid Butyrate Imprints an Antimicrobial Program in Macrophages. Immunity 2019, 50, 432-445.e7. [CrossRef]

18. Smith, P.M.; Howitt, M.R.; Panikov, N.; Michaud, M.; Gallini, C.A.; Bohlooly-Y, M.; Glickman, J.N.; Garrett, W.S. The microbial metabolites, short-chain fatty acids, regulate colonic treg cell homeostasis. Science 2013, 341, 569-573. [CrossRef]

19. Atarashi, K.; Tanoue, T.; Oshima, K.; Suda, W.; Nagano, Y.; Nishikawa, H.; Fukuda, S.; Saito, T.; Narushima, S.; Hase, K.; et al. Treg induction by a rationally selected mixture of Clostridia strains from the human microbiota. Nature 2013, 500, 232-236. [CrossRef]

20. Wallace, R.J. Ruminal microbial metabolism of peptides and amino acids. J. Nutr. 1996, 126 (Suppl. 4), 1326S-1334S. [CrossRef]

21. Wu, G.D.; Chen, J.; Hoffmann, C.; Bittinger, K.; Chen, Y.Y.; Keilbaugh, S.A.; Bewtra, M.; Knights, D.; Walters, W.A.; Knight, R.; et al. Linking long-term dietary patterns with gut microbial enterotypes. Science 2011, 334, 105-108. [CrossRef]

22. Wiertsema, S.P.; van Bergenhenegouwen, J.; Garssen, J.; Knippels, L.M.J. The Interplay between the Gut Microbiome and the Immune System in the Context of Infectious Diseases throughout Life and the Role of Nutrition in Optimizing Treatment Strategies. Nutrients 2021, 13, 886. [CrossRef]

23. Kinoshita, H.; Uchida, H.; Kawai, Y.; Kitazawa, H.; Miura, K.; Shiiba, K.; Horii, A.; Saito, T. Quantitative evaluation of adhesion of lactobacilli isolated from human intestinal tissues to human colonic mucin using surface plasmon resonance (BIACORE assay). $J$. Appl. Microbiol. 2007, 102, 116-123. [CrossRef] [PubMed]

24. Sicard, J.-F.; Vogeleer, P.; Le Bihan, G.; Olivera, Y.R.; Beaudry, F.; Jacques, M.; Harel, J. N-Acetyl-glucosamine influences the biofilm formation of Escherichia coli. Gut Pathog. 2018, 10, 26. [CrossRef] [PubMed]

25. Johansson, M.E.; Jakobsson, H.E.; Holmén-Larsson, J.; Schütte, A.; Ermund, A.; Rodríguez-Piñeiro, A.M.; Arike, L.; Wising, C.; Svensson, F.; Bäckhed, F.; et al. Normalization of Host Intestinal Mucus Layers Requires Long-Term Microbial Colonization. Cell Host Microbe 2015, 18, 582-592. [CrossRef]

26. Sekirov, I.; Russell, S.L.; Antunes, L.C.; Finlay, B.B. Gut microbiota in health and disease. Physiol. Rev. 2010, 90, 859-904. [CrossRef] [PubMed]

27. Buffie, C.G.; Pamer, E.G. Microbiota-mediated colonization resistance against intestinal pathogens. Nat. Rev. Immunol. 2013, 13, 790-801. [CrossRef] 
28. Coquant, G.; Grill, J.-P.; Seksik, P. Impact of N-Acyl-Homoserine Lactones, Quorum Sensing Molecules, on Gut Immunity. Front. Immunol. 2020, 11, 1827. [CrossRef] [PubMed]

29. Piewngam, P.; Zheng, Y.; Nguyen, T.H.; Dickey, S.W.; Joo, H.-S.; Villaruz, A.E.; Glose, K.A.; Fisher, E.L.; Hunt, R.L.; Li, B.; et al. Pathogen elimination by probiotic Bacillus via signalling interference. Nature 2018, 562, 532-537. [CrossRef]

30. Bouskra, D.; Brézillon, C.; Bérard, M.; Werts, C.; Varona, R.; Boneca, I.G.; Eberl, G. Lymphoid tissue genesis induced by commensals through NOD1 regulates intestinal homeostasis. Nature 2008, 456, 507-510. [CrossRef] [PubMed]

31. Iacob, S.; Iacob, D.G.; Luminos, L.M. Intestinal Microbiota as a Host Defense Mechanism to Infectious Threats. Front. Microbiol. 2019, 9, 3328. [CrossRef] [PubMed]

32. Hooper, L.V.; Stappenbeck, T.S.; Hong, C.V.; Gordon, J.I. Angiogenins: A new class of microbicidal proteins involved in innate immunity. Nat. Immunol. 2003, 4, 269-273. [CrossRef]

33. Cash, H.L.; Whitham, C.V.; Behrendt, C.L.; Hooper, L.V. Symbiotic bacteria direct expression of an intestinal bactericidal lectin. Science 2006, 313, 1126-1130. [CrossRef] [PubMed]

34. Pütsep, K.; Axelsson, L.-G.; Boman, A.; Midtvedt, T.; Normark, S.; Boman, H.G.; Andersson, M. Germ-free and colonized mice generate the same products from enteric prodefensins. J. Biol. Chem. 2000, 275, 40478-40482. [CrossRef] [PubMed]

35. Hapfelmeier, S.; Lawson, M.A.; Slack, E.; Kirundi, J.K.; Stoel, M.; Heikenwalder, M.; Cahenzli, J.; Velykoredko, Y.; Balmer, M.L.; Endt, K.; et al. Reversible microbial colonization of germ-free mice reveals the dynamics of IgA immune responses. Science 2010, 328, 1705-1709. [CrossRef]

36. Umesaki, Y.; Okada, Y.; Matsumoto, S.; Imaoka, A.; Setoyama, H. segmented filamentous bacteria are indigenous intestinal bacteria that activate intraepithelial lymphocytes and induce MHC class II molecules and fucosyl asialo gm1 glycolipids on the small intestinal epithelial cells in the ex-germ-free mouse. Microbiol. Immunol. 1995, 39, 555-562. [CrossRef]

37. Gaboriau-Routhiau, V.; Rakotobe, S.; Lecuyer, E.; Mulder, I.; Lan, A.; Bridonneau, C.; Rochet, V.; Pisi, A.; De Paepe, M.; Brandi, G.; et al. The key role of segmented filamentous bacteria in the coordinated maturation of gut helper T cell responses. Immunity 2009, 31, 677-689. [CrossRef]

38. Ivanov, I.I.; Atarashi, K.; Manel, N.; Brodie, E.L.; Shima, T.; Karaoz, U.; Wei, D.; Goldfarb, K.C.; Santee, C.A.; Lynch, S.V.; et al. Induction of intestinal Th17 cells by segmented filamentous bacteria. Cell 2009, 139, 485-498. [CrossRef]

39. Umesaki, Y.; Setoyama, H.; Matsumoto, S.; Imaoka, A.; Itoh, K. Differential roles of segmented filamentous bacteria and clostridia in development of the intestinal immune system. Infect. Immun. 1999, 67, 3504-3511. [CrossRef]

40. Moyes, D.L.; Naglik, J.R. Mucosal immunity and candida albicans infection. Clin. Dev. Immunol. 2011, 2011, 346307. [CrossRef]

41. Fukata, M.; Arditi, M. The role of pattern recognition receptors in intestinal inflammation. Mucosal Immunol. 2013, 6, 451-463. [CrossRef] [PubMed]

42. Wang, M.; Ahrnã, S.; Jeppsson, B.; Molin, G. Comparison of bacterial diversity along the human intestinal tract by direct cloning and sequencing of 16S rRNA genes. FEMS Microbiol. Ecol. 2005, 54, 219-231. [CrossRef] [PubMed]

43. Price, A.E.; Shamardani, K.; Lugo, K.A.; Deguine, J.; Roberts, A.W.; Lee, B.L.; Barton, G.M. A Map of Toll-like Receptor Expression in the Intestinal Epithelium Reveals Distinct Spatial, Cell Type-Specific, and Temporal Patterns. Immunity 2018, 49, 560-575.e6. [CrossRef] [PubMed]

44. Abreu, M.T.; Thomas, L.S.; Arnold, E.T.; Lukasek, K.; Michelsen, K.S.; Arditi, M. TLR signaling at the intestinal epithelial interface. J. Endotoxin Res. 2003, 9, 322-330. [CrossRef]

45. Melmed, G.; Thomas, L.S.; Lee, N.; Tesfay, S.Y.; Lukasek, K.; Michelsen, K.S.; Zhou, Y.; Hu, B.; Arditi, M.; Abreu, M.T. Human intestinal epithelial cells are broadly unresponsive to Toll-like receptor 2-dependent bacterial ligands: Implications for hostmicrobial interactions in the gut. J. Immunol. 2003, 170, 1406-1415. [CrossRef]

46. Szebeni, B.; Veres, G.; Dezsõfi, A.; Rusai, K.; Vannay, Á.; Mraz, M.; Majorova, E.; Arató, A. Increased expression of Toll-like receptor (TLR) 2 and TLR4 in the colonic mucosa of children with inflammatory bowel disease. Clin. Exp. Immunol. 2008, 151, 34-41. [CrossRef]

47. Frolova, L.; Drastich, P.; Rossmann, P.; Klimesova, K.; Tlaskalova-Hogenova, H. Expression of Toll-like receptor 2 (TLR2), TLR4, and CD14 in biopsy samples of patients with inflammatory bowel diseases: Upregulated expression of TLR2 in terminal ileum of patients with ulcerative colitis. J. Histochem. Cytochem. 2008, 56, 267-274. [CrossRef]

48. Gewirtz, A.T.; Navas, T.A.; Lyons, S.; Godowski, P.J.; Madara, J.L. Cutting edge: Bacterial flagellin activates basolaterally expressed TLR5 to induce epithelial proinflammatory gene expression. J. Immunol. 2001, 167, 1882-1885. [CrossRef]

49. Iliev, I.D.; Funari, V.A.; Taylor, K.D.; Nguyen, Q.; Reyes, C.N.; Strom, S.P.; Brown, J.; Becker, C.A.; Fleshner, P.R.; Dubinsky, M.; et al. Interactions between commensal fungi and the C-type lectin receptor dectin-1 influence colitis. Science 2012, 336, $1314-1317$. [CrossRef]

50. Sokol, H.; Conway, K.L.; Zhang, M.; Choi, M.; Morin, B.; Cao, Z.; Villablanca, E.J.; Li, C.; Wijmenga, C.; Yun, S.H.; et al. Card9 mediates intestinal epithelial cell restitution, T-helper 17 responses, and control of bacterial infection in mice. Gastroenterology 2013, 145, 591-601.e3. [CrossRef]

51. Lamas, B.; Richard, M.L.; Leducq, V.; Pham, H.-P.; Michel, M.-L.; DA Costa, G.; Bridonneau, C.; Jegou, S.; Hoffmann, T.W.; Natividad, J.M.; et al. CARD9 impacts colitis by altering gut microbiota metabolism of tryptophan into aryl hydrocarbon receptor ligands. Nat. Med. 2016, 22, 598-605. [CrossRef]

52. Sartor, R.B. Therapeutic manipulation of the enteric microflora in inflammatory bowel diseases: Antibiotics, probiotics, and prebiotics. Gastroenterology 2004, 126, 1620-1633. [CrossRef] 
53. Kostic, A.D.; Xavier, R.J.; Gevers, D. The microbiome in inflammatory bowel disease: Current status and the future ahead. Gastroenterology 2014, 146, 1489-1499. [CrossRef] [PubMed]

54. Lee, M.; Chang, E.B. Inflammatory Bowel Diseases (IBD) and the Microbiome-Searching the Crime Scene for Clues. Gastroenterology 2021, 160, 524-537. [CrossRef]

55. Alipour, M.; Zaidi, D.; Valcheva, R.; Jovel, J.; Martínez, I.; Sergi, C.; Walter, J.; Mason, A.L.; Wong, G.K.; Dieleman, L.A.; et al. Mucosal Barrier Depletion and Loss of Bacterial Diversity are Primary Abnormalities in Paediatric Ulcerative Colitis. J. Crohn's Colitis 2016, 10, 462-471. [CrossRef]

56. Darfeuille-Michaud, A.; Boudeau, J.; Bulois, P.; Neut, C.; Glasser, A.-L.; Barnich, N.; Bringer, M.-A.; Swidsinski, A.; Beaugerie, L.; Colombel, J.-F. High prevalence of adherent-invasive Escherichia coli associated with ileal mucosa in Crohn's disease. Gastroenteroogy 2004, 127, 412-421. [CrossRef]

57. Subramanian, S.; Rhodes, J.M.; Hart, C.A.; Tam, B.; Roberts, C.L.; Smith, S.L.; Corkill, J.E.; Winstanley, C.; Virji, M.; Campbell, B.J. Characterization of epithelial IL-8 response to inflammatory bowel disease mucosal E. coli and its inhibition by mesalamine. Inflamm. Bowel Dis. 2008, 14, 162-175. [CrossRef]

58. Rowan, F.; Docherty, N.G.; Murphy, M.; Murphy, B.; Coffey, J.C.; O’Connell, P.R. Desulfovibrio bacterial species are increased in ulcerative colitis. Dis. Colon Rectum 2010, 53, 1530-1536. [CrossRef] [PubMed]

59. Png, C.W.; Lindén, S.K.; Gilshenan, K.S.; Zoetendal, E.G.; McSweeney, C.S.; Sly, L.I.; McGuckin, M.A.; Florin, T.H. Mucolytic bacteria with increased prevalence in IBD mucosa augment in vitro utilization of mucin by other bacteria. Am. J. Gastroenterol. 2010, 105, 2420-2428. [CrossRef] [PubMed]

60. Zhou, L.; Zhang, M.; Wang, Y.; Dorfman, R.G.; Liu, H.; Yu, T.; Chen, X.; Tang, D.; Xu, L.; Yin, Y.; et al. Faecali bacterium prausnitzii Produces Butyrate to Maintain Th17/Treg Balance and to Ameliorate Colorectal Colitis by Inhibiting Histone Deacetylase 1. Inflamm. Bowel Dis. 2018, 24, 1926-1940. [CrossRef]

61. Varela, E.; Manichanh, C.; Gallart, M.; Torrejón, A.; Borruel, N.; Casellas, F.; Guarner, F.; Antolin, M. Colonisation byFaecalibacterium prausnitziiand maintenance of clinical remission in patients with ulcerative colitis. Aliment. Pharmacol. Ther. 2013, 38, 151-161. [CrossRef] [PubMed]

62. Takahashi, K.; Nishida, A.; Fujimoto, T.; Fujii, M.; Shioya, M.; Imaeda, H.; Inatomi, O.; Bamba, S.; Sugimoto, M.; Andoh, A. Reduced Abundance of Butyrate-Producing Bacteria Species in the Fecal Microbial Community in Crohn's Disease. Digestion 2016, 93, 59-65. [CrossRef] [PubMed]

63. Pitcher, M.C.; Beatty, E.R.; Cummings, J.H. The contribution of sulphate reducing bacteria and 5-aminosalicylic acid to faecal sulphide in patients with ulcerative colitis. Gut 2000, 46, 64-72. [CrossRef]

64. Kaufman, J.; Griffiths, T.A.; Surette, M.G.; Ness, S.; Rioux, K.P. Effects of mesalamine (5-aminosalicylic acid) on bacterial gene expression. Inflamm. Bowel Dis. 2009, 15, 985-996. [CrossRef] [PubMed]

65. Magnusson, M.K.; Strid, H.; Sapnara, M.; Lasson, A.; Bajor, A.; Ung, K.-A.; Öhman, L. Anti-TNF Therapy Response in Patients with Ulcerative Colitis Is Associated with Colonic Antimicrobial Peptide Expression and Microbiota Composition. J. Crohn's Colitis 2016, 10, 943-952. [CrossRef]

66. Swidsinski, A.; Loening-Baucke, V.; Bengmark, S.; Lochs, H.; Dörffel, Y. Azathioprine and mesalazine-induced effects on the mucosal flora in patients with IBD colitis. Inflamm. Bowel Dis. 2007, 13, 51-56. [CrossRef] [PubMed]

67. Huang, E.Y.; Inoue, T.; Leone, V.A.; Dalal, S.; Touw, K.; Wang, Y.; Musch, M.W.; Theriault, B.; Higuchi, K.; Donovan, S.; et al. Using corticosteroids to reshape the gut microbiome: Implications for inflammatory bowel diseases. Inflamm. Bowel Dis. 2015, 21, 963-972. [CrossRef] [PubMed]

68. Hyun, Y.S.; Han, D.S.; Lee, A.R.; Eun, C.S.; Youn, J.; Kim, H.-Y. Role of IL-17A in the development of colitis-associated cancer. Carcinogenesis 2012, 33, 931-936. [CrossRef]

69. Kado, S.; Uchida, K.; Funabashi, H.; Iwata, S.; Nagata, Y.; Ando, M.; Onoue, M.; Matsuoka, Y.; Ohwaki, M.; Morotomi, M. Intestinal microflora are necessary for development of spontaneous adenocarcinoma of the large intestine in T-cell receptor beta chain and p53 double-knockout mice. Cancer Res. 2001, 61, 2395-2398.

70. Yachida, S.; Mizutani, S.; Shiroma, H.; Shiba, S.; Nakajima, T.; Sakamoto, T.; Watanabe, H.; Masuda, K.; Nishimoto, Y.; Kubo, M.; et al. Metagenomic and metabolomic analyses reveal distinct stage-specific phenotypes of the gut microbiota in colorectal cancer. Nat. Med. 2019, 25, 968-976. [CrossRef]

71. Richard, M.L.; Liguori, G.; Lamas, B.; Brandi, G.; da Costa, G.; Hoffmann, T.W.; Di Simone, M.P.; Calabrese, C.; Poggioli, G.; Langella, P.; et al. Mucosa-associated microbiota dysbiosis in colitis associated cancer. Gut Microbes 2018, 9, 131-142. [CrossRef]

72. Appleyard, C.B.; Cruz, M.L.; Isidro, A.A.; Arthur, J.C.; Jobin, C.; De Simone, C. Pretreatment with the probiotic VSL\#3 delays transition from inflammation to dysplasia in a rat model of colitis-associated cancer. Am. J. Physiol. Gastrointest. Liver Physiol. 2011, 301, G1004-G1013. [CrossRef]

73. Talero, E.; Bolivar, S.; Ávila-Román, J.; Alcaide, A.; Fiorucci, S.; Motilva, V. Inhibition of chronic ulcerative colitis-associated adenocarcinoma development in mice by VSL\#3. Inflamm. Bowel Dis. 2015, 21, 1027-1037. [CrossRef]

74. Arthur, J.C.; Gharaibeh, R.Z.; Uronis, J.M.; Perez-Chanona, E.; Sha, W.; Tomkovich, S.; Mühlbauer, M.; Fodor, A.A.; Jobin, C. VSL\#3 probiotic modifies mucosal microbial composition but does not reduce colitis-associated colorectal cancer. Sci. Rep. 2013, 3, 2868. [CrossRef]

75. Abreu, M.T. Toll-like receptor signalling in the intestinal epithelium: How bacterial recognition shapes intestinal function. Nat. Rev. Immunol. 2010, 10, 131-144. [CrossRef] 
76. Fukata, M.; Chen, A.; Vamadevan, A.S.; Cohen, J.; Breglio, K.; Krishnareddy, S.; Hsu, D.; Xu, R.; Harpaz, N.; Dannenberg, A.J.; et al. Toll-like receptor-4 promotes the development of colitis-associated colorectal tumors. Gastroenterology 2007, 133, 1869-1881. [CrossRef]

77. Rakoff-Nahoum, S.; Medzhitov, R. Regulation of spontaneous intestinal tumorigenesis through the adaptor protein MyD88. Science 2007, 317, 124-127. [CrossRef] [PubMed]

78. Kim, S.W.; Kim, H.M.; Yang, K.M.; Kim, S.-A.; Kim, S.-K.; An, M.J.; Park, J.J.; Lee, S.K.; Kim, T.I.; Kim, W.H.; et al. Bifidobacterium lactis inhibits NF- $\mathrm{KB}$ in intestinal epithelial cells and prevents acute colitis and colitis-associated colon cancer in mice. Inflamm. Bowel Dis. 2010, 16, 1514-1525. [CrossRef]

79. Wu, S.; Rhee, K.-J.; Albesiano, E.; Rabizadeh, S.; Wu, X.; Yen, H.-R.; Huso, D.L.; Brancati, F.L.; Wick, E.; McAllister, F.; et al. A human colonic commensal promotes colon tumorigenesis via activation of T helper type $17 \mathrm{~T}$ cell responses. Nat. Med. 2009, 15, 1016-1022. [CrossRef] [PubMed]

80. Arthur, J.C.; Perez-Chanona, E.; Mühlbauer, M.; Tomkovich, S.; Uronis, J.M.; Fan, T.-J.; Campbell, B.J.; Abujamel, T.; Dogan, B.; Rogers, A.B.; et al. Intestinal inflammation targets cancer-inducing activity of the microbiota. Science 2012, 338, 120-123. [CrossRef] [PubMed]

81. Maddocks, O.D.; Short, A.J.; Donnenberg, M.S.; Bader, S.; Harrison, D.J. Attaching and effacing Escherichia coli downregulate DNA mismatch repair protein in vitro and are associated with colorectal adenocarcinomas in humans. PLoS ONE 2009, 4, e5517. [CrossRef]

82. Vieira, E.L.; Leonel, A.J.; Sad, A.P.; Beltrão, N.R.; Costa, T.F.; Ferreira, T.M.; Gomes-Santos, A.C.; Faria, A.M.; Peluzio, M.C.; Cara, D.C.; et al. Oral administration of sodium butyrate attenuates inflammation and mucosal lesion in experimental acute ulcerative colitis. J. Nutr. Biochem. 2012, 23, 430-436. [CrossRef] [PubMed]

83. Sivaprakasam, S.; Bhutia, Y.D.; Yang, S.; Ganapathy, V. Short-Chain Fatty Acid Transporters: Role in Colonic Homeostasis. Compr. Physiol. 2017, 8, 299-314. [CrossRef] [PubMed]

84. Kim, I.-W.; Myung, S.-J.; Do, M.Y.; Ryu, Y.-M.; Kim, M.J.; Do, E.-J.; Park, S.; Yoon, S.M.; Ye, B.D.; Byeon, J.-S.; et al. Western-style diets induce macrophage infiltration and contribute to colitis-associated carcinogenesis. J. Gastroenterol. Hepatol. 2010, 25, 1785-1794. [CrossRef]

85. Furusawa, Y.; Obata, Y.; Fukuda, S.; Endo, T.A.; Nakato, G.; Takahashi, D.; Nakanishi, Y.; Uetake, C.; Kato, K.; Kato, T.; et al. Commensal microbe-derived butyrate induces the differentiation of colonic regulatory T cells. Nature 2013, 504, 446-450. [CrossRef] [PubMed]

86. Ladoire, S.; Martin, F.; Ghiringhelli, F. Prognostic role of FOXP3+ regulatory T cells infiltrating human carcinomas: The paradox of colorectal cancer. Cancer Immunol. Immunother. 2011, 60, 909-918. [CrossRef]

87. Mittal, D.E.; Gubin, M.M.; Schreiber, R.D.; Smyth, M.J. New insights into cancer immunoediting and its three component phases-elimination, equilibrium and escape. Curr. Opin. Immunol. 2014, 27, 16-25. [CrossRef]

88. Salama, P.; Phillips, M.; Grieu, F.; Morris, M.; Zeps, N.; Joseph, D.; Platell, C.; Iacopetta, B. Tumor-infiltrating FOXP3+ T regulatory cells show strong prognostic significance in colorectal cancer. J. Clin. Oncol. 2009, 27, 186-192. [CrossRef]

89. Saito, T.; Nishikawa, H.; Wada, H.; Nagano, Y.; Sugiyama, D.; Atarashi, K.; Maeda, Y.; Hamaguchi, M.; Ohkura, N.; Sato, E.; et al. Two FOXP3+CD4+ T cell subpopulations distinctly control the prognosis of colorectal cancers. Nat. Med. 2016, 22, 679-684. [CrossRef]

90. Ohnmacht, C.; Park, J.-H.; Cording, S.; Wing, J.B.; Atarashi, K.; Obata, Y.; Gaboriau-Routhiau, V.; Marques, R.; Dulauroy, S.; Fedoseeva, M.; et al. Mucosal Immunology. The microbiota regulates type 2 immunity through ROR $\gamma \mathrm{t}+\mathrm{T}$ cells. Science 2015, 349, 989-993. [CrossRef] [PubMed]

91. Quandt, J.; Arnovitz, S.; Haghi, L.; Woehlk, J.; Mohsin, A.; Okoreeh, M.; Mathur, P.S.; Emmanuel, A.O.; Osman, A.; Krishnan, M.; et al. Wnt- $\beta$-catenin activation epigenetically reprograms Treg cells in inflammatory bowel disease and dysplastic progression. Nat. Immunol. 2021, 22, 471-484. [CrossRef]

92. World Health Organization. Coronavirus Disease (COVID-19) Pandemic. Available online: https://www.who.int/emergencies/ diseases / novel-coronavirus-2019 (accessed on 1 December 2021).

93. Sungnak, W.; Huang, N.; Becavin, C.; Berg, M.; Queen, R.; Litvinukova, M.; Talavera-Lopez, C.; Maatz, H.; Reichart, D.; Sampaziotis, F.; et al. SARS-CoV-2 entry factors are highly expressed in nasal epithelial cells together with innate immune genes. Nat. Med. 2020, 26, 681-687. [CrossRef]

94. Lamers, M.M.; Beumer, J.; van der Vaart, J.; Knoops, K.; Puschhof, J.; Breugem, T.I.; Ravelli, R.; Paul van Schayck, J.; Mykytyn, A.Z.; Duimel, H.Q.; et al. SARS-CoV-2 productively infects human gut enterocytes. Science 2020, 369, 50-54. [CrossRef]

95. Ye, Q.; Wang, B.; Zhang, T.; Xu, J.; Shang, S. The mechanism and treatment of gastrointestinal symptoms in patients with COVID-19. Am. J. Physiol. Gastrointest. Liver Physiol. 2020, 319, G245-G252. [CrossRef]

96. Elmunzer, B.J.; Spitzer, R.L.; Foster, L.D.; Merchant, A.A.; Howard, E.F.; Patel, V.A.; West, M.K.; Qayed, E.; Nustas, R.; Zakaria, A.; et al. North American Alliance for the Study of Digestive Manifestations of COVID-19. Digestive Manifestations in Patients Hospitalized with Coronavirus Disease 2019. Clin. Gastroenterol. Hepatol. 2021, 19, 1355-1365.e4. [CrossRef] [PubMed]

97. Sulaiman, T.; Algharawi, A.A.; Idrees, M.; Alzaidy, R.H.; Faris, K.; Cullingford, G.; Rasheed, J. The prevalence of gastrointestinal symptoms among patients with COVID-19 and the effect on the severity of the disease. JGH Open 2020, 4, 1162-1166, Advance online publication. [CrossRef] 
98. Pan, L.; Mu, M.; Yang, P.; Sun, Y.; Wang, R.; Yan, J.; Li, P.; Hu, B.; Wang, J.; Hu, C.; et al. Clinical Characteristics of COVID-19 Patients with Digestive Symptoms in Hubei, China: A Descriptive, Cross-Sectional, Multicenter Study. Am. J. Gastroenterol. 2020, 115, 766-773. [CrossRef] [PubMed]

99. Hayashi, Y.; Wagatsuma, K.; Nojima, M.; Yamakawa, T.; Ichimiya, T.; Yokoyama, Y.; Kazama, T.; Hirayama, D.; Nakase, H. The characteristics of gastrointestinal symptoms in patients with severe COVID-19: A systematic review and meta-analysis. J. Gastroenterol. 2021, 56, 409-420. [CrossRef]

100. Perisetti, A.; Goyal, H.; Gajendran, M.; Boregowda, U.; Mann, R.; Sharma, N. Prevalence, Mechanisms, and Implications of Gastrointestinal Symptoms in COVID-19. Front. Med. 2020, 7, 588711. [CrossRef]

101. Coomes, E.A.; Haghbayan, H. Interleukin-6 in Covid-19: A systematic review and meta-analysis. Rev. Med. Virol. 2020, 30, 1-9. [CrossRef]

102. Buckholz, A.; Kaplan, A.; Jessurun, J.; De Jong, Y.; Crawford, C. Microthrombosis associated with GI bleeding in COVID-19. Gastrointest. Endosc. 2021, 93, 263-264. [CrossRef]

103. Yamakawa, T.; Ishigami, K.; Takizawa, A.; Takada, Y.; Ohwada, S.; Yokoyama, Y.; Kazama, T.; Hirayama, D.; Yoshii, S.; Yamano, H.-O.; et al. Extensive mucosal sloughing of the small intestine and colon in a patient with severe COVID-19. DEN Open 2021, 2, e42. [CrossRef]

104. Zuo, T.; Zhang, F.; Lui, G.; Yeoh, Y.K.; Li, A.; Zhan, H.; Wan, Y.; Chung, A.; Cheung, C.P.; Chen, N.; et al. Alterations in Gut Microbiota of Patients With COVID-19 During Time of Hospitalization. Gastroenterology 2020, 159, 944-955.e8. [CrossRef]

105. Gu, S.; Chen, Y.; Wu, Z.; Chen, Y.; Gao, H.; Lv, L.; Guo, F.; Zhang, X.; Luo, R.; Huang, C.; et al. Alterations of the Gut Microbiota in Patients with Coronavirus Disease 2019 or H1N1 Influenza. Clin. Infect. Dis. 2020, 71, 2669-2678. [CrossRef]

106. Yeoh, Y.K.; Zuo, T.; Lui, G.C.; Zhang, F.; Liu, Q.; Li, A.Y.; Chung, A.C.; Cheung, C.P.; Tso, E.Y.; Fung, K.S.; et al. Gut microbiota composition reflects disease severity and dysfunctional immune responses in patients with COVID-19. Gut 2021, 70, 698-706. [CrossRef] 